\title{
Insights from the Molecular modeling, docking analysis of illicit drugs and Bomb Compounds with Honey Bee Odorant Binding Proteins (OBPs)
}

\author{
Kulanthaivel Langeswaran ${ }^{*}$, Jeyakanthan Jeyaraman ${ }^{1}$, Richard Mariadasse ${ }^{1}$, Saravanan \\ Soorangkattan ${ }^{2}$
}

${ }^{1}$ Department of Bioinformatics, Alagappa University, Karaikudi-630 003; 2Department of Botany, Alagappa University, Karaikudi - 630 003; Langeswaran VK - E-mail: dr.langeswaran@gmail.com; *Corresponding author

Received March 3, 2018; Revised April 19, 2018; Accepted April 20, 2018; Published May 31, 2018

doi: $10.6026 / 97320630014219$

Abstract:

Analysis of honeybee PBPs is of interest in the development of Biosensor applications. We described the predicted binding of 19 such compounds with 43-honey bee OBPs using molecular modeling, docking and phylogenetic analysis. Therefore, training the honeybees using preferred compounds formulate the bees to identify the illicit drugs and bomb compounds. Consequently, high docking score produced complex such OBP16-N-Phenyl-2-Napthalamine $(-12.25 \mathrm{k} / \mathrm{mol})$, 3BJH-Crack Cocaine $(-11.75 \mathrm{k} / \mathrm{mol})$, OBP10-Methadone ($11.71 \mathrm{k} / \mathrm{mol})$, 1TUJ-Dronobinal Cannabis $(-11.66 \mathrm{k} / \mathrm{mol})$, OBP13-Plasticizer $(-11.27 \mathrm{k} / \mathrm{mol})$ and OBP24-Ecstasy $(-10.89 \mathrm{k} / \mathrm{mol}) \mathrm{can}$ be used to identify the compounds using biosensor application. The chemical reaction of the compounds for olfactory sensory was analyzed using DFT (Density Functional Theory) studies. Some of these compounds show high binding OBPs across distant phylogeny.

Keywords: Biosensor, Docking, DFT, Honey Bee, Illicit drugs, OBPs, olfactory sensory and Phylogenetic tree

\section{Background:}

In 2013, it was estimated that 24.6 million people around the age group of 12 , which is approximately $9.4 \%$ of the population using Illicit drugs in America. It is also found that 5\% (i.e. 230 million) of world's adult population is consuming Illicit drugs [1]. The most commonly available drugs are cannabis, heroin, opium, methadone, amphetamine, cocaine and hashish etc. Drug addiction is a vital problem in their families and it directly gives way to financial crises of family income and health issues [2]. Also, these illicit drugs are directly affecting the health of the person and gives approximately 0.2 million deaths per year, in which, heroin and cocaine are major causative agents [1].

Sniffer dogs have the ability to smell and detect the crime, but their ability threshold of smell is lesser than commercially available analytics $[3,4]$. Moreover, in terms of disadvantage, the cost and training duration is huge in the short term and the biased activities of trainer, can lead the dogs to perform positive or negative response [5]. Recently, the US government announced, cannabis drug is legalized in the country therefore; detection by sniffer dogs cannot be taken as evidence for the probe of crime [6-8]. Therefore, the alternative solution using insects can be a better idea of the identification of illicit drugs [3]. The high smell sensing nature and learning capability, insect is an alternative biosensor application.

One among the insect is a honeybee. There are several types of honeybees present globally but Apis mellifera (western honey bee) and Apis cerena (Asian honey bee) are significant [9] among them. Honeybee has high sensing capacity and detect the odor compounds in the floating air and find the place where the source of food available [10]. Honeybees have more than 177 odorant binding genes that are responsible for the detection of volatile compounds [11]. The antennae of honeybee are more sensitive and useful for detecting the volatile compounds [12]. Recent research suggesting that, training the honeybees can detect and locate the bomb compound TATP (triacetone 


\section{Open access}

triperoxide); therefore, the explosive material can be easily identified. [13]

Honeybee's chemical communication occurs via the acid watersoluble proteins that recognized the airborne hydrophobic odorant compound to olfactory sensing systems. These proteins can be classified as Odorant binding protein (OBPs), Pheromone Binding Protein (PBPs) and chemosensory proteins (CSPs). In which, OBPs are commonly used to recognize various odorant compounds binding specificity and induce the first step signal to the olfactory sense. PBPs constituent in general, male bees detect the sex pheromones released by the queen bees. CSPs proteins recognized the chemical compound for the communication of insects.

OBPs of honeybee classified three Antenna Specific Proteins (ASPs) such as ASP1, ASP2 and ASP3 diverse in the antenna and functioning differently. ASP1 protein belongs to pheromone binding protein (PBP) since it binds to detect the 9-keto-2(E)decenoic acid and 9-hydroxy-2 (E)-decenoicacid of queen pheromones. ASP2 proteins consist of diverse sequence variation with PBPs therefore; pheromones did not bind with ASP2 protein considered as OBPs. The ASP3 proteins are highly homologous with the CBPs groups that classified under CBPs protein. Among these proteins, ASP2 is well-characterized OBPs proteins for binding affinities of ligand and volatile compounds. Homologous of ASP2 protein with other OBP protein structures may depict the functional concurrence of ligand binding affinity for olfactory sensory.

The rational approach towards the identification of elicit drugs and bomb compounds using honey bee Odorant binding proteins are most important phenomena for the identification of compounds [3]. The computational approaches are the most successive method for understanding the binding preferences and the chemical reaction of the biological function. In this study, we have performed phylogenetic tree, extensive docking and DFT studies to understand the binding mechanism and the mode of illicit drugs and bomb compounds interactions with OBPs of honeybee [14]. As consequent, honey bee and OBPs can be used in two different ways based on the binding preference and binding score [15]. If the binding preferences of illicit drugs and bomb compounds are high towards OBPs, it can train the honey bees to identify the source compounds, whereas, if the binding score (scoring functions are fast approximate mathematical methods used to predict the strength of the interaction (also referred to as binding affinity) between two molecules after they have been docked) is high, we can develop the molecular biosensor application using respective OBPs to detect the illicit drugs and bomb compounds. This method may pave the application towards the identification of illicit drugs and bomb compounds using honeybee Odorant Binding Protein.

\section{Methodology: \\ Compounds and Protein collection from Databases:}

The easily available nineteen illicit drugs and bomb compounds were obtained from the literature studies $(R, S)$ and the 3Dimentional structures of the compounds were retrieved from ISSN 0973-2063 (online) 0973-8894 (print) the PubChem database [16] (Table 1) Nineteen illicit drugs drugs and bomb compounds collected from PubChem database). Threedimensional structure of 10 Odorant binding proteins (OBPs) and 33-odorant binding protein sequences of honeybee were retrieved from PDB and UniProt database [17]. Retrieved sequences were further used to construct the 3-D model using Swiss-model server [18] to understand the secondary structure elements and structural proteins. Totally, 43 OBP structures and 19 illicit drugs and bomb compounds were used for the further studies.

\section{Sequence, Secondary Structural element and phylogenetic tree analysis:}

All the 43 sequences of OBPs were used to perform the multiple sequence alignment using Clustal $W$ [19] and the functional domain of the proteins was identified using CDD server [20] to understand the contribution of sensing nature. The phylogenetic tree analyses were performed using Mega 7 software [21] and JTT amino acid substitution model was used to generate the tree with the bootstrap value of 1000 . One sequence from each clade was taken and their 3-D structure was superimposed to understand based on the secondary structure element. The structure based phylogenetic tree was constructed and the relation between the protein structures was analyzed [22].

\section{Ligand Preparation:}

3-D structures of all the illicit drugs and bomb compounds were prepared using LigPrep module implemented in the Schrodinger software suite, version 3.3 [23]. The implicit hydrogen was removed and appropriate hydrogen atoms were added to the structures for the minimization. The unwanted water molecules were removed. The expand protonation and tautomeric states at $7.0 \pm 2.0 \mathrm{pH}$ units were applied in order to generate the lowest energy structures of the illicit drugs and bomb compounds. The Partial atomic charges were computed using the OPLS_2005 force field [24].

\section{Protein Preparation:}

The retrieved 33 OBPs sequences were used to develop the 3-D model of protein using Swiss Model [18] and 10 structures taken from PDB database were considered as receptor molecules. The OBPs proteins were prepared and refined using protein preparation wizard implemented in the Schrodinger software suite [22]. The hydrogen atoms were consistently added to the protein structures with the $\mathrm{pH} 7.0 \pm 2.0$ subsequently minimized with Optimized Potential for Liquid Simulation (OPLS-2005) all atom force field [23]. Energy minimization was performed to constraining the heavy atoms with the hydrogen torsion parameter turned off, to allow free rotation of hydrogen atoms. Restrained minimization was terminated until the maximum Root-mean-square deviation of non-hydrogen atoms reaches 0.3 $\AA$. The proteins can use to predict the active site packet using Sitemap module [26] to generate the active site zone and the Grid [27] was generated to dock with volatile compounds [23].

\section{Docking studies:}

The Docking studies of 19 compounds with 43 OBP proteins were performed usingXP mode using Schrödinger software suite [23]. The active site residues of OBPs and their interactions were 


\section{Open access}

identified using Ligplot module. The 19 compounds preference is highly relying upon active site cavity and charged surface of the OBP proteins. The compounds and the 2D ligand interaction diagram will indicate the type of interactions with the key amino acid residues in the active site of OBP. Based on the Docking score and Binding free energy, the potential compounds will be detected and predict specific compound attracting the honeybee to find out the illicit drugs and bomb compounds [3].

\section{Molecular property analysis of proteins:}

The molecular electrostatic potential surface of the OBPs was carried out using PyMol Software (Schrodinger, LLC) [28]. The charged density of the proteins can prefer the compounds to bind to the active site of the proteins. Binding selectivity of the compounds highly depends upon the nature of the protein surface. The positive surface denoted by the blue color region and the red color region indicated negatively charged regions. The neutral region denoted by the white color (protein 6 (GAS6) and protein S (PROS1).

\section{DFT calculation:}

In the quantum, mechanical calculation, DFT calculates the molecular electronic features such as electron density and frontier molecular orbital (HOMO and LUMO) to predict the biological activity and molecular features of the compounds [29]. Geometry optimization was performed using a hybrid DFT approach at B3LYP (Becke's three-parameter exchange potential and the LeeYang-Parr correlation functional) with $6-31 G^{*}$ basis set. The Poisson-Boltzmann solver was used to calculate the energy in aqueous condition to simulate a physiological condition, which provides the information about the global and local indices of ligand molecules to their biological activity. The spatial distributions of electronic features in charge transfer mechanism are obtained from the HOMO and LUMO molecular orbitals. All DFT calculations were carried out using Jaguar, version 8.7 [29] to define the role of illicit drugs and bomb compounds.

\section{Result \& Discussion:}

Sequence, secondary Structure and phylogenetic tree analysis: The sequence analysis of 43 OBPs sand the secondary structural element were analyzed. The result enlightens all the OBPs sequences are similar in nature and consist of conserved and semi-conserved residues within the group of organisms. Cysteine residue falls highly conserved in all the sequences, whereas, Glycine, Glutamic acid, Aspartic acid, Valine, Lysine, Methionine, Glutamine, Threonine, and Asparagine amino acids found to have conserved within some OBPs (Figure 1). Cysteine residue in OBPs may contribute the protein stability and Lysine, Asparagine, Aspartic acid, Glutamic acid may contribute to the charged surface of the OBPs. Moreover, there is no conserved domain constituent in the all the OBPs sequences, therefore, the structural foldmay differ from one to other proteins. All the 43 OBPs consist of six or seven $\alpha$-helices in the structure. Due to this, the active site pocket surface of the proteins may influence the binding affinity of the compounds. Depends upon the amino acid composition of proteins, the electrostatic surface and their based binding selectivity of compounds can differ. Moreover, the structural superimposed of $43 \mathrm{OBP}$ proteins reveals that 26 ISSN 0973-2063 (online) 0973-8894 (print) proteins secondary structural elements were retained in the structural integrity and remaining 16 proteins consist different folds of secondary structural elements. This difference in the structure leads to focus on the structural aspect to investigate the binding mode of illicit drugs and bomb compound and their related biological function. The structure based phylogenetic tree approach leads to understanding the structural similarity of OBPs and their electrostatic attribute to determine the binding specificity of compound (Figure 2). The relationship among the OBPs of ApisCerana and ApisMillifera organism was identified using phylogenetic tree analysis. The tree consists of three major clades and out-group of rooted tree depicting the ancestral lineage. The OBP16 and OBP23 proteins belong to Apis Cerana and Apis Millifera family of honeybee proteins are highly homologous in their sequences and the structure. The bootstrap value of phylogenetic tree explores the less noise with good quality of the tree. Moreover, superimposition of protein structures from each clade were depicts, structural folds of OBPs are highly similar and could find the difference in the binding cavity of the protein surface which determines the selectivity of compounds according to the binding sites (Figure 3). Apis Cerana and Apis Millifera has highly homologous in the sequences and the structural properties, therefore it can be a better model if we produced the any of one protein from two different organisms. The structural evolution of OBPs based on the phylogenetic tree shown in (Figure 4).

\section{Molecular electrostatic potential surface analysis:}

The molecular electrostatic potential analysis was performed for each OBP from different clades of the phylogenetic tree to understand the contribution of the charged density of the proteins for the binding specificity of the compounds. Six proteins from different group of the organism were accounted and the electrostatic surface was analyzed. Interestingly, modeled OBP16 and OBP23 protein structures belong to Apismillifera and Apiscerana honey that consists of positive and neutral charged surfaces in organism depicts the similar binding cavities. In the case of Clade 1 and II, OBP4 and OBP2structurallyhomologous and the electrostatic surface showed that positive surface located in OBP4 protein whereas OBP2protein consists of negative charged surface. The modeled structure of OBP22 and $2 \mathrm{H} 8 \mathrm{~V}$ crystal structures from Clade 4 and 5 showed that modeled OBP22 protein structure consists of a positive surface whereas $2 \mathrm{H} 8 \mathrm{~V}$ protein consists of negatively charged in the active site pockets. Charged residues in the active site pocket of the proteins contributed the binding selectivity and affinity of the compounds. Also, amino acid substitutions in the active site pockets confer the differential electrostatic surface and binding cavities volume to the binding of compounds therefore, the proteins may have undergone the structural divergence and present in the different cladesphylo genetic tree. This may contribute the binding preference of the 19 illicit drugs and bomb compounds for binding selectivity according to amino acid substitutes and electrostatic surfaces. The electrostatic interactions of OBPs were shown in (Figure 5) to understand the charged surfaces of six proteins taken from the phylogenetic tree. 


\section{Open access}

Docking studies of illicit drugs and bomb compounds:

Docking studies were performed using all the 19 compounds with each 43 proteins to understand the binding specificity and the mode of interactions. This entire work is highly relied upon binding of illicit drugs and bomb compounds and not on neither docking score nor preferences (how many proteins prefer one compound) of the compound. Therefore, we fix criteria that docking score is more than $-10.00 \mathrm{kcal} / \mathrm{mol}$ is considered as better docking score. Result enlightens that, all the compounds were not found to have a better binding score (Below -10.00 $\mathrm{kcal} / \mathrm{mol}$ ) and only 11 compounds show a high binding affinity with more than $-10.00 \mathrm{kcal} / \mathrm{mol}$ with OBPs (Table 1). Docking of N-Phenyl-2-Napthalamine with modeled Q8WRW4 protein have a high docking score of $-12.25 \mathrm{k} / \mathrm{mol}$. Likewise, 3BJH-Crack Cocaine $(-11.75 \mathrm{k} / \mathrm{mol})$, H6BYY1-Methadone $(-11.71 \mathrm{k} / \mathrm{mol}), 1 \mathrm{TUJ}-$ Dronobinal Cannabis (-11.66k/mol), S5CRW7-Plasticizer ($11.27 \mathrm{k} / \mathrm{mol})$ and Q1W1E0- Ecstasy $(-10.89 \mathrm{k} / \mathrm{mol})$ shows the high docking score with the selective specificity of the compounds. Interestingly, the bomb compounds of N-Phenyl-2-Napthalamine $(-12.25 \mathrm{k} / \mathrm{mol})$ shows the high docking score with OBPs followed by that, Crack cocaine $(-11.75 \mathrm{k} / \mathrm{mol})$ shows the better docking score in the active site pocket of proteins. Moreover, different types of interactions like $\mathrm{H}$-bond interaction, $\mathrm{Pi}$-Pi interaction and ionic interaction found with the OBPs of the honeybee to favor the reactions. Compounds such as Amphetamine, methamphetamine and N-Phenyl-2-napthalamine are aminecontaining moiety therefore, it forms $\mathrm{H}$-bond with negatively charged residues of the proteins [30]. Moreover, Binder Styrene Butadiene and methadone compounds consist of one or two aromatic rings in the structure therefore, it could not form any $\mathrm{H}$ bond interactions rather it forms pi-pi stacking with respective proteins with high docking score. Most of the interactions were found to have charged amino acids such as Aspartic acids and positively charged amino acids Arginine in the active site pocket. Depends upon the interactions, the biological function of the honeybee detecting may vary per the compounds. The docking score of all the compounds with respective OBPs is shown in (Table 2). The interaction of residues of all the compounds and their mode of interactions depicted in the (Figure 6). High docking score prefers the compound to bind well in the active site pocket. Based on this study, we can use these proteins at molecular level biosensor application to detect or identify the illicit drugs and bomb compounds.

\footnotetext{
Binding selectivity analysis of illicit drugs and bomb compounds using OBPs:

Here we have analyzed the Binding preference of illicit drugs and bomb compounds with 43 OBPs (Details of 43 OBPs given in Table 3). Docking of 19 compounds with 43 OBPs, each protein may often prefer one compound; therefore, the probability of signaling mechanism in honeybee may induce the memory to identify the compounds. Hence, the training of those compounds with honeybee leads to identify the compounds where it is present. Among the 43 OBPs, several proteins highly binding prefer Crack Cocaine, Plasticizer, N-Phenyl-2-Napthalamine, Dronobinal Cannabis, Ecstasy, Benzodiazepine, Binder styrene Butadiene and Methadone predominantly in the active site of proteins. This binding nature can induce high sensing power of ISSN 0973-2063 (online) 0973-8894 (print)
}

honeybee to memories and detect the compound in the respective source of food. Observing from this study, training of honeybee using those compounds can be easy to identify the bomb and illegal drugs. Because of high selectivity compounds toward the binding would be important for the sensing nature of honeybees. Figure 7 shows the binding selectivity of the illicit drugs and bomb compounds.

\section{DFT studies analysis:}

DFT study implies the frontier orbital energy including Highest Occupied Molecular Orbital (HOMO) and Lowest Unoccupied Molecular Orbital (LUMO) to understand the electron transfer feature of eleven compounds. The electron donor/acceptor properties of the molecules were indicated by the distribution of frontier molecular orbital's that illustrates the favorable sites for nucleophilic (HOMO) and electrophilic (LUMO) attack during charge transfer reaction. The HOMO and LUMO energy gap defines the internal charge transfer interaction among the compounds. Lowering gap energy implied the less stability with high chemical reaction of the compounds. The compounds Amphetamine, Ecstasy, N-Phenyl-2-Napthalamine, Benzodiazepine, Dronobinal Cannabis, Crack Cocaine, Methamphetamine, and narcotine consist of one or more aromatic rings, lipophilic and aliphatic groups in the chemical moiety. Therefore, it is important for the discrimination of honeybee OBPs for binding and recognition of the olfactory system [31]. HOMO-LUMO regions are localized in aromatic, lipophilic, aliphatic, amine $\left(-\mathrm{NH}_{3}\right)$ and hydroxyl groups $(-\mathrm{OH})$ of N-Phenyl-2-Napthalamine, Benzodiazepine, Crack Cocaine, Methamphetamine and narcotine compounds form H-bond, pi-pi stacking and Cation-pi stacks interaction interactions with Leu, Lys, Val, Asp and Asn amino acids for chemosensory signaling reaction for honey bees olfactory system (Venthur et al. 2014). It has been reported that aromatic, lipophilic and aliphatic group of ligand molecules are important features for binding affinity and chemosensory signaling in OBPs. This HOMO-LUMO energy gap is the improved indicator for electron transport mechanism in the molecule. All the compounds have low HOMO-LUMO energy gaps shown in (Table 4). This interaction may favor for the recognition and identification of illicit drugs and bomb compounds. The stability of the reactions was identified using HOMO-LUMO gap that renders that, all the compounds may have more reactive with less band gap for the biological reactions. The HOMO-LUMO regions of eleven illicit drugs and bomb compounds were shown in (Figure 8 \& 9).

Table 1: Nineteen illicit drugs and bomb compounds collected from PubChem database.

\begin{tabular}{clc} 
S .no & Compound name & PubChem ID \\
\hline 1 & Rdx & 8490 \\
2 & Binder styrene Butadiene & 62697 \\
3 & Trinitrotoluene & 69044 \\
4 & Semte & 56841778 \\
5 & Ecstasy & 1615 \\
6 & Methadone & 4095 \\
7 & Narcotic & 4544 \\
8 & Crack cocaine & 5760 \\
9 & Amphetamine & 5826 \\
\hline
\end{tabular}




\begin{tabular}{llc}
\hline 10 & Petn & 6518 \\
11 & N-phenyl-2-Napthalamine & 8398 \\
12 & Methamphetamine & 10836 \\
13 & Dronobinal cannabis & 16078 \\
14 & Plasticizer & 66540 \\
15 & Benzodiazepine & 134664 \\
16 & Crack Cocaine & 446220 \\
17 & Tri-cyclic acetone peroxide & 4380970 \\
18 & Heroine & 5462328 \\
19 & Bath salt mdpv & 20111961 \\
\hline
\end{tabular}

Table 2: Docking score of 43 proteins with 19 Illicit drugs and bomb compounds.

\begin{tabular}{|c|c|c|c|}
\hline $\begin{array}{l}\text { PubChem } \\
\text { ID }\end{array}$ & PROTEIN ID & Compound name & $\begin{array}{l}\text { Docking } \\
\text { score }\end{array}$ \\
\hline $\begin{array}{l}66540 \\
16078\end{array}$ & 1TUJ & $\begin{array}{l}\text { Plasticizer } \\
\text { Dronobinal cannabis }\end{array}$ & $\begin{array}{l}-6.876 \\
-6.650\end{array}$ \\
\hline $\begin{array}{l}5826 \\
1615\end{array}$ & $2 \mathrm{H} 8 \mathrm{~V}$ & $\begin{array}{l}\text { Amphetamine } \\
\text { Ecstasy }\end{array}$ & $\begin{array}{l}-6.824 \\
-6.505\end{array}$ \\
\hline $\begin{array}{l}1615 \\
5760\end{array}$ & 3BJH & $\begin{array}{l}\text { Ecstasy } \\
\text { Crack cocaine }\end{array}$ & $\begin{array}{l}-10.894 \\
-10.864\end{array}$ \\
\hline $\begin{array}{l}66540 \\
5760\end{array}$ & $3 \mathrm{CYZ}$ & $\begin{array}{l}\text { Plasticizer } \\
\text { Crack cocaine }\end{array}$ & $\begin{array}{l}-10.142 \\
-9.491\end{array}$ \\
\hline $\begin{array}{l}7658 \\
6054\end{array}$ & $3 \mathrm{D} 73$ & $\begin{array}{l}\text { Phenylethyl butanoate } \\
\text { Phenethyl alcohosl }\end{array}$ & $\begin{array}{l}-9.209 \\
-7.901\end{array}$ \\
\hline $\begin{array}{l}5760 \\
8398\end{array}$ & 3D75 & $\begin{array}{l}\text { Crack cocaine } \\
\text { N-phenyl-2-napthylamine }\end{array}$ & $\begin{array}{l}-10.445 \\
-10.052\end{array}$ \\
\hline $\begin{array}{l}8398 \\
5760\end{array}$ & 3FE6 & $\begin{array}{l}\text { N-phenyl-2-napthylamine } \\
\text { Crack cocaine }\end{array}$ & $\begin{array}{l}-10.807 \\
-10.311\end{array}$ \\
\hline $\begin{array}{l}66540 \\
8398\end{array}$ & $3 R 72$ & $\begin{array}{l}\text { Plasticizer } \\
\text { N-phenyl-2-napthylamine }\end{array}$ & $\begin{array}{l}-8.604 \\
-7.925\end{array}$ \\
\hline $\begin{array}{l}134664 \\
62697\end{array}$ & $3 R Z S$ & $\begin{array}{l}\text { Benzodiazepine } \\
\text { Binder styrene butadiene }\end{array}$ & $\begin{array}{l}-8.980 \\
-6.340\end{array}$ \\
\hline $\begin{array}{l}134664 \\
5826\end{array}$ & $3 S O A$ & $\begin{array}{l}\text { Benzodiazepine } \\
\text { Amphetamine }\end{array}$ & $\begin{array}{l}-8.113 \\
-5.992\end{array}$ \\
\hline $\begin{array}{l}5760 \\
5760\end{array}$ & 3D75 & $\begin{array}{l}\text { Crack cocaine } \\
\text { Crack cocaine }\end{array}$ & $\begin{array}{l}-10.445 \\
-9.837\end{array}$ \\
\hline $\begin{array}{l}16078 \\
66540\end{array}$ & $3 \mathrm{D} 78$ & $\begin{array}{l}\text { Dronobinal cannabis } \\
\text { Plasticizer }\end{array}$ & $\begin{array}{l}-11.667 \\
-10.861\end{array}$ \\
\hline $\begin{array}{l}5826 \\
62697\end{array}$ & $\begin{array}{l}\text { AOAOA7RDX8 } \\
\text { (OBP1) }\end{array}$ & $\begin{array}{l}\text { Amphetamine } \\
\text { Binder styrene butadiene }\end{array}$ & $\begin{array}{l}-6.477 \\
-6.329\end{array}$ \\
\hline $\begin{array}{l}134664 \\
62697\end{array}$ & $\begin{array}{l}\text { AOAOKOPX79 } \\
\text { (OBP2) }\end{array}$ & $\begin{array}{l}\text { Benzodiazepine } \\
\text { Binder styrene butadiene }\end{array}$ & $\begin{array}{l}-6.509 \\
-6.224\end{array}$ \\
\hline $\begin{array}{l}134664 \\
5826\end{array}$ & $\begin{array}{l}\text { AOAOKOPX82 } \\
\text { (OBP3) }\end{array}$ & $\begin{array}{l}\text { Benzodiazepine } \\
\text { Amphetamine }\end{array}$ & $\begin{array}{l}-8.851 \\
-6.173\end{array}$ \\
\hline $\begin{array}{l}5760 \\
16078\end{array}$ & $\begin{array}{l}\text { AOAOKOРХH2 } \\
\text { (OBP4) }\end{array}$ & $\begin{array}{l}\text { Crack cocaine } \\
\text { Dronobinal cannabis }\end{array}$ & $\begin{array}{l}-4.650 \\
-4.645\end{array}$ \\
\hline $\begin{array}{l}4095 \\
66540\end{array}$ & $\begin{array}{l}\text { AOAOKOРXY3 } \\
\text { (OBP5) }\end{array}$ & $\begin{array}{l}\text { Methadone } \\
\text { Plasticizer }\end{array}$ & $\begin{array}{l}-10.493 \\
-9.186\end{array}$ \\
\hline $\begin{array}{l}134664 \\
5826\end{array}$ & $\begin{array}{l}\text { AOAOU2SP42 } \\
\text { (OBP6) }\end{array}$ & $\begin{array}{l}\text { Benzodiazepine } \\
\text { Amphetamine }\end{array}$ & $\begin{array}{l}6.891 \\
-6.164\end{array}$ \\
\hline 134664 & AOAOU2SQWO & Benzodiazepine & -8.913 \\
\hline
\end{tabular}

ISSN 0973-2063 (online) 0973-8894 (print)

Bioinformation 14(5): 219-231 (2018)

\begin{tabular}{|c|c|c|c|}
\hline 62697 & (OBP7) & Binder styrene butadiene & -6.220 \\
\hline $\begin{array}{l}16078 \\
10836\end{array}$ & $\begin{array}{l}\text { AOAOU2UB85 } \\
\text { (OBP8) }\end{array}$ & $\begin{array}{l}\text { Dronobinal cannabis } \\
\text { Methamphetamine }\end{array}$ & $\begin{array}{l}-3.588 \\
-3.174\end{array}$ \\
\hline $\begin{array}{l}5760 \\
4095\end{array}$ & $\begin{array}{l}\text { H6VYYO } \\
\text { (OBP9) }\end{array}$ & $\begin{array}{l}\text { Crack cocaine } \\
\text { Methadone }\end{array}$ & $\begin{array}{l}-11.537 \\
-10.642\end{array}$ \\
\hline $\begin{array}{l}5760 \\
4095\end{array}$ & $\begin{array}{l}\text { H6VYY1 } \\
\text { (OBP10) }\end{array}$ & $\begin{array}{l}\text { Crack cocaine } \\
\text { Methadone }\end{array}$ & $\begin{array}{l}-11.758 \\
-11.712\end{array}$ \\
\hline $\begin{array}{l}134664 \\
62697\end{array}$ & $\begin{array}{l}\text { V9IM79 } \\
\text { (OBP11) }\end{array}$ & $\begin{array}{l}\text { Benzodiazepine } \\
\text { Binder styrene butadiene }\end{array}$ & $\begin{array}{l}-6.503 \\
-6.208\end{array}$ \\
\hline $\begin{array}{l}5826 \\
66540\end{array}$ & $\begin{array}{l}\text { AOAOU2SR55 } \\
\text { (OBP12) }\end{array}$ & $\begin{array}{l}\text { Amphetamine } \\
\text { Plasticizer }\end{array}$ & $\begin{array}{l}-4.334 \\
-4.174\end{array}$ \\
\hline $\begin{array}{l}66540 \\
16078\end{array}$ & $\begin{array}{l}\text { S5CRW7 } \\
\text { (OBP13) }\end{array}$ & $\begin{array}{l}\text { Plasticizer } \\
\text { Dronobinal cannabis }\end{array}$ & $\begin{array}{l}-10.322 \\
-9.993\end{array}$ \\
\hline $\begin{array}{l}16078 \\
66540\end{array}$ & Q8WRW3 (OBP14) & $\begin{array}{l}\text { Dronobinal cannabis } \\
\text { Plasticizer }\end{array}$ & $\begin{array}{l}-8.409 \\
-7.879\end{array}$ \\
\hline $\begin{array}{l}5760 \\
5760\end{array}$ & Q8WRW4 (OBP15) & $\begin{array}{l}\text { Crack cocaine } \\
\text { Crack cocaine }\end{array}$ & $\begin{array}{l}-6.500 \\
-6.294\end{array}$ \\
\hline $\begin{array}{l}8398 \\
66540\end{array}$ & Q8WRW5 (OBP16) & $\begin{array}{l}\text { N-phenyl-2-napthylamine } \\
\text { Plasticizer }\end{array}$ & $\begin{array}{l}-12.253 \\
-10.559\end{array}$ \\
\hline $\begin{array}{l}8398 \\
66540\end{array}$ & $\begin{array}{l}\text { Q8WRW5 } \\
\text { (OBP17) }\end{array}$ & $\begin{array}{l}\text { N-phenyl-2-napthylamine } \\
\text { Plasticizer }\end{array}$ & $\begin{array}{l}-12.087 \\
-11.274\end{array}$ \\
\hline $\begin{array}{l}5760 \\
4095\end{array}$ & Q8WRW6 (OBP18) & $\begin{array}{l}\text { Crack cocaine } \\
\text { Methadone }\end{array}$ & $\begin{array}{l}-6.415 \\
-6.356\end{array}$ \\
\hline $\begin{array}{l}62697 \\
1615\end{array}$ & $\begin{array}{l}\text { Q9U9J5 } \\
\text { (OBP19) }\end{array}$ & $\begin{array}{l}\text { Binder styrenebutadiene } \\
\text { Ecstasy }\end{array}$ & $\begin{array}{l}-5.639 \\
-2.584\end{array}$ \\
\hline $\begin{array}{l}5760 \\
5760\end{array}$ & $\begin{array}{l}\text { Q9U9J5 } \\
\text { (OBP20) }\end{array}$ & $\begin{array}{l}\text { Crack cocaine } \\
\text { Crack cocaine }\end{array}$ & $\begin{array}{l}-7.549 \\
-7.516\end{array}$ \\
\hline $\begin{array}{l}8398 \\
66540\end{array}$ & $\begin{array}{l}\text { Q9U9J6_ASP1 } \\
\text { (OBP21) }\end{array}$ & $\begin{array}{l}\text { N-phenyl-2-napthylamine } \\
\text { Plasticizer }\end{array}$ & $\begin{array}{l}-12.087 \\
-11.274\end{array}$ \\
\hline $\begin{array}{l}5826 \\
10836\end{array}$ & $\begin{array}{l}\text { Q1W1D7 } \\
\text { (OBP22) }\end{array}$ & $\begin{array}{l}\text { Amphetamine } \\
\text { Methamphetamine }\end{array}$ & $\begin{array}{l}-5.763 \\
-5.015\end{array}$ \\
\hline $\begin{array}{l}1615 \\
8398\end{array}$ & $\begin{array}{l}\text { Q1W1D8 } \\
\text { (OBP23) }\end{array}$ & $\begin{array}{l}\text { Ecstasy } \\
\text { N-phenyl-2-napthylamine }\end{array}$ & $\begin{array}{l}-5.128 \\
-4.655\end{array}$ \\
\hline $\begin{array}{l}16078 \\
1615\end{array}$ & $\begin{array}{l}\text { Q1W1E0 } \\
\text { (OBP24) }\end{array}$ & $\begin{array}{l}\text { Dronobinal cannabis } \\
\text { Ecstasy }\end{array}$ & $\begin{array}{l}-7.604 \\
-6.752\end{array}$ \\
\hline $\begin{array}{l}5760 \\
5760\end{array}$ & $\begin{array}{l}\text { Q5VK57 } \\
\text { (OBP25) }\end{array}$ & $\begin{array}{l}\text { Crack cocaine } \\
\text { Crack cocaine }\end{array}$ & $\begin{array}{l}-7.195 \\
-7.136\end{array}$ \\
\hline $\begin{array}{l}4095 \\
4544\end{array}$ & $\begin{array}{l}\text { V91HTO } \\
\text { (OBP26) }\end{array}$ & $\begin{array}{l}\text { Methadone } \\
\text { Narcotine }\end{array}$ & $\begin{array}{l}-3.336 \\
-3.080\end{array}$ \\
\hline $\begin{array}{l}8398 \\
5826\end{array}$ & MODEL 2 (OBP27) & $\begin{array}{l}\text { N-phenyl-2-Napthylamine } \\
\text { amphetamine }\end{array}$ & $\begin{array}{l}-5.308 \\
-5.173\end{array}$ \\
\hline $\begin{array}{l}8398 \\
66540\end{array}$ & Q8WRW2 (OBP28) & $\begin{array}{l}\text { N-phenyl-2-Napthylamine } \\
\text { plasticizer }\end{array}$ & $\begin{array}{l}-7.749 \\
-7.082\end{array}$ \\
\hline $\begin{array}{l}8398 \\
5826\end{array}$ & $\begin{array}{l}\text { V9VFX4 } \\
\text { (OBP29) }\end{array}$ & $\begin{array}{l}\text { N-phenyl-2-Napthylamine } \\
\text { Amphetamine }\end{array}$ & $\begin{array}{l}-5.308 \\
-5.173\end{array}$ \\
\hline $\begin{array}{l}5760 \\
1615\end{array}$ & $\begin{array}{l}\text { V91F66 } \\
\text { (OBP30) }\end{array}$ & $\begin{array}{l}\text { Crack cocaine } \\
\text { Ecstasy }\end{array}$ & $\begin{array}{l}-8.578 \\
-7.867\end{array}$ \\
\hline $\begin{array}{l}1615 \\
5826\end{array}$ & $\begin{array}{l}\text { X2GEC7 } \\
\text { (OBP31) }\end{array}$ & $\begin{array}{l}\text { Ecstasy } \\
\text { Amphetamine }\end{array}$ & $\begin{array}{l}-6.243 \\
-6.079\end{array}$ \\
\hline
\end{tabular}




\section{BIOINFORMATION}

\section{Discovery at the interface of physical and biological sciences}

\section{Open access}

Table 3: Sequence information and source of organism of 43 OBPs.

\begin{tabular}{llll}
\hline S.no & Protein Id & Sequence Id & Source of organism \\
\hline 1 & 1TUJ & Q9U9J5 & Apis mellifera \\
2 & 2H8V & Q8WRW5 & Apis mellifera \\
3 & 3BJH & Q8WRW5 & Apis mellifera \\
4 & 3CYZ & Q9U9J6 & Apis mellifera \\
5 & 3D73 & Q9U9J6 & Apis mellifera \\
6 & 3D75 & Q9U9J6 & Apis mellifera \\
7 & 3FE6 & Q9U9J6 & Apis mellifera \\
8 & 3R72 & Q8WRW2 & Apis mellifera \\
9 & 3RZS & Q1W640 & Apis mellifera \\
10 & 3SOA & Q9UQM7 & Apis mellifera \\
11 & 3D75 & Q9U9J6 & Apis mellifera \\
12 & 3D78 & Q9U9J6 & Apis mellifera \\
13 & OBP 17 & A0A0A7RDX8 & Apis cerana cerana \\
14 & OBP 21 & A0A0K0PX79 & Apis cerana cerana \\
15 & OBP 14 & A0A0K0PX82 & Apis cerana cerana \\
16 & OBP 12 & A0A0K0PXH2 & Apis cerana cerana \\
17 & OBP 15 & A0A0U2SP42 & Apis cerana cerana \\
18 & OBP 14 & A0A0U2SQW0 & Apis cerana cerana \\
19 & OBP 12 & A0A0U2UB85 & Apis cerana cerana \\
20 & OBP 1 & H6VYY0 & Apis cerana cerana \\
21 & OBP 1 & H6VYY1 & Apis cerana cerana \\
22 & OBP 21 & V9IM79 & Apis cerana cerana \\
23 & OBP 13 & A0A0U2SR55 & Apis cerana cerana \\
24 & OBP OBP11 & S5CRW7 & Apis cerana cerana \\
25 & OBP ASP6 & Q8WRW3 & Apis mellifera \\
26 & OBP ASP4 & Q8WRW4 & Apis mellifera \\
27 & OBP ASP1 & Q8WRW5 & Apis mellifera \\
28 & OBP ASP1 & Q8WRW5 & Apis mellifera \\
29 & OBP ASP4 & Q8WRW6 & Apis mellifera \\
30 & OBP ASP2 & Q9U9J5 & Apis mellifera \\
31 & OBP ASP2 & Q9U9J5 & Apis mellifera \\
32 & PBPASP1 & Q9U9J6 & Apis mellifera \\
33 & OBP ASP1 & Q1W1D7 & Apis cerana cerana \\
\hline & & &
\end{tabular}

\begin{tabular}{llll}
\hline 34 & OBP ASP3 & Q1W1D8 & Apis cerana cerana \\
35 & OBP ASP2 & Q1W1E0 & Apis cerana cerana \\
36 & OBP 24 & Q1WI24 & Apis cerana cerana \\
37 & OBP ASP4 & Q5VK57 & Apis cerana cerana \\
38 & OBP 23 & Q6VK37 & Apis cerana cerana \\
39 & OBP 27 & Q9WY56 & Homo sapiens \\
40 & OBP ASP5 & Q8WRW2 & Apis mellifera \\
41 & OBP 3 & V9VFX4 & Apis cerana \\
42 & OBP 10 & V9IF66 & Apis cerana \\
43 & OBP 3 & X2GEC7 & Apis cerana \\
\hline \multicolumn{7}{l}{ OBP - Odorant Binding Protein; PBP - Pheromone-binding protein }
\end{tabular}

Table 4: DFT analysis result for the top eleven illicit drugs and bomb compounds.

\begin{tabular}{lllll}
\hline Compounds & $\begin{array}{l}\text { HOMO } \\
(\mathbf{e V})\end{array}$ & $\begin{array}{l}\text { LUMO } \\
(\mathbf{e V})\end{array}$ & $\begin{array}{l}\text { E }_{\text {Hомо- }} \\
\text { ELUM }^{(\mathbf{e V})}\end{array}$ & $\begin{array}{l}\text { Solv.Energy } \\
(\mathbf{k c a l} / \mathbf{m o l})\end{array}$ \\
\hline Crack Cocaine & -0.24 & -0.05 & -0.18 & -0.05 \\
$\begin{array}{l}\text { Plasticizer } \\
\text { N-Phenyl-2- }\end{array}$ & -0.26 & -0.07 & -0.19 & -0.05 \\
$\begin{array}{l}\text { Napthalamine } \\
\text { Dronobinal Cannabis }\end{array}$ & -0.21 & -0.01 & -0.20 & -0.05 \\
$\begin{array}{l}\text { Benzodiazepine } \\
\text { Binder styrene }\end{array}$ & -0.21 & -0.00 & -0.21 & -0.05 \\
Butadiene & -0.18 & -0.07 & -0.11 & -0.05 \\
Methadone & -0.24 & -0.01 & -0.22 & -0.05 \\
Narcotine & -0.23 & -0.04 & -0.18 & -0.05 \\
Methamphetamine & -0.21 & -0.06 & -0.14 & -0.05 \\
Ecstasy & -0.23 & -0.00 & -0.22 & -0.05 \\
Amphetamine & -0.21 & -0.01 & -0.19 & -0.05 \\
\hline & -0.24 & -0.01 & -0.23 & -0.05 \\
\hline
\end{tabular}

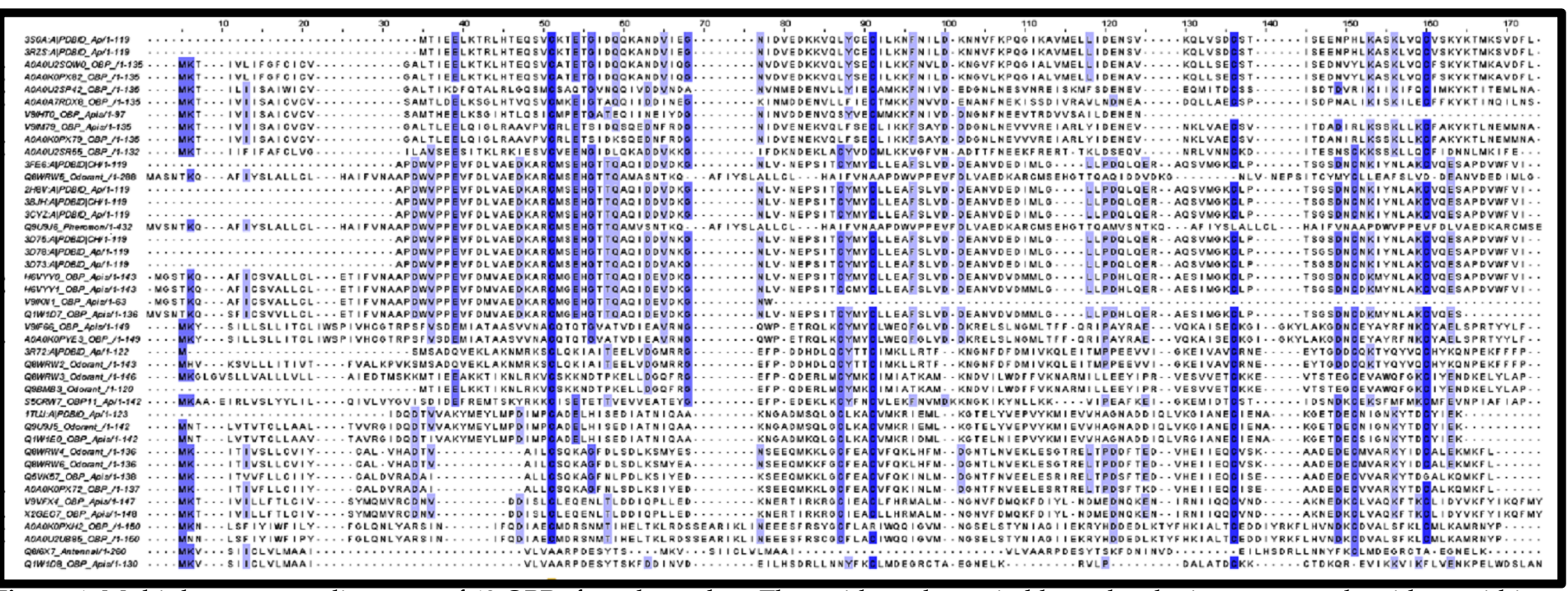

Figure 1: Multiple sequence alignment of 43 OBPs from honeybee. The residues shown in blue color depicts conserved residues within the group of organisms. 


\section{BIOINFORMATION \\ Discovery at the interface of physical and biological sciences}

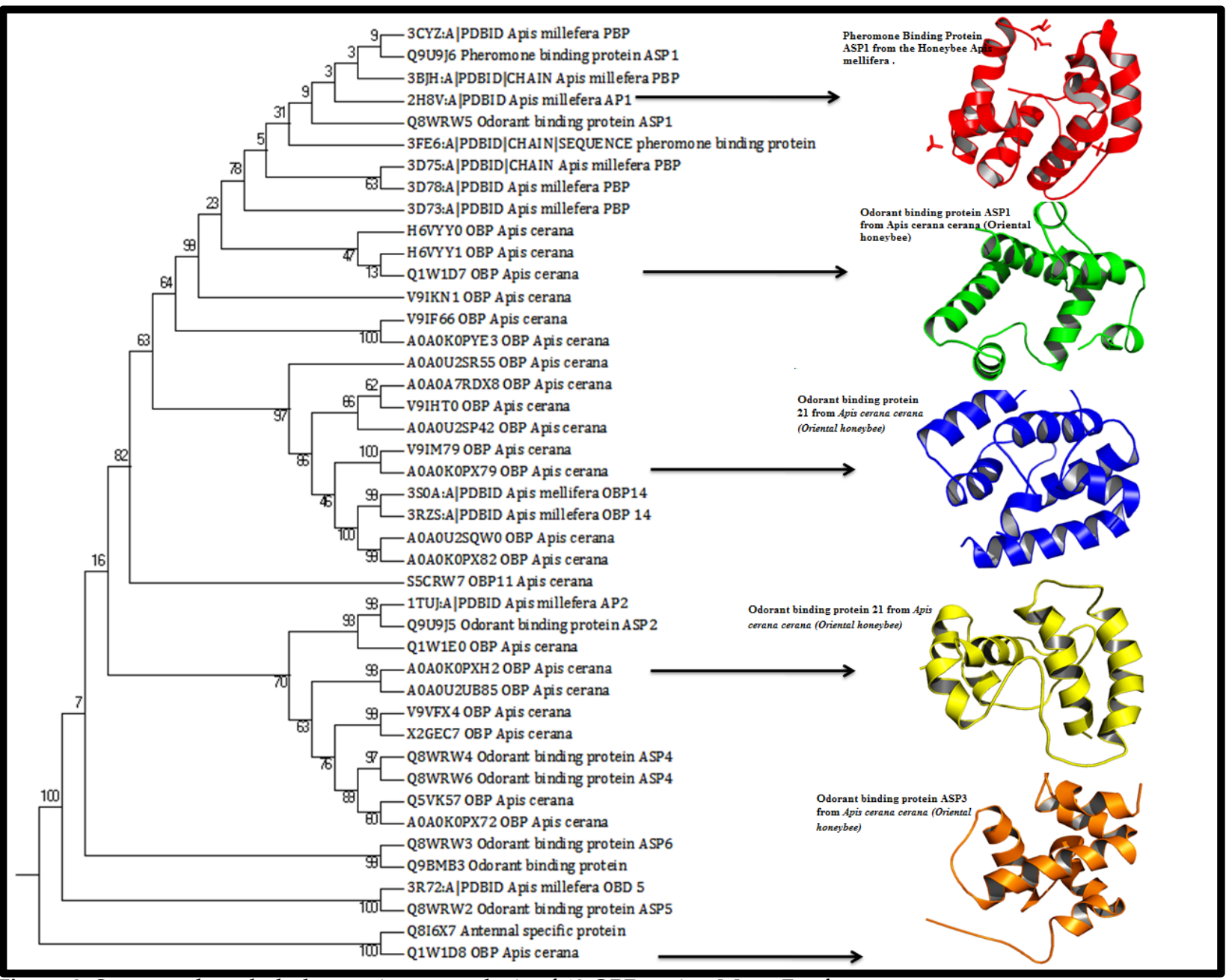

Figure 2: Structure based phylogenetic tree analysis of 43 OBPs using Mega 7 software.

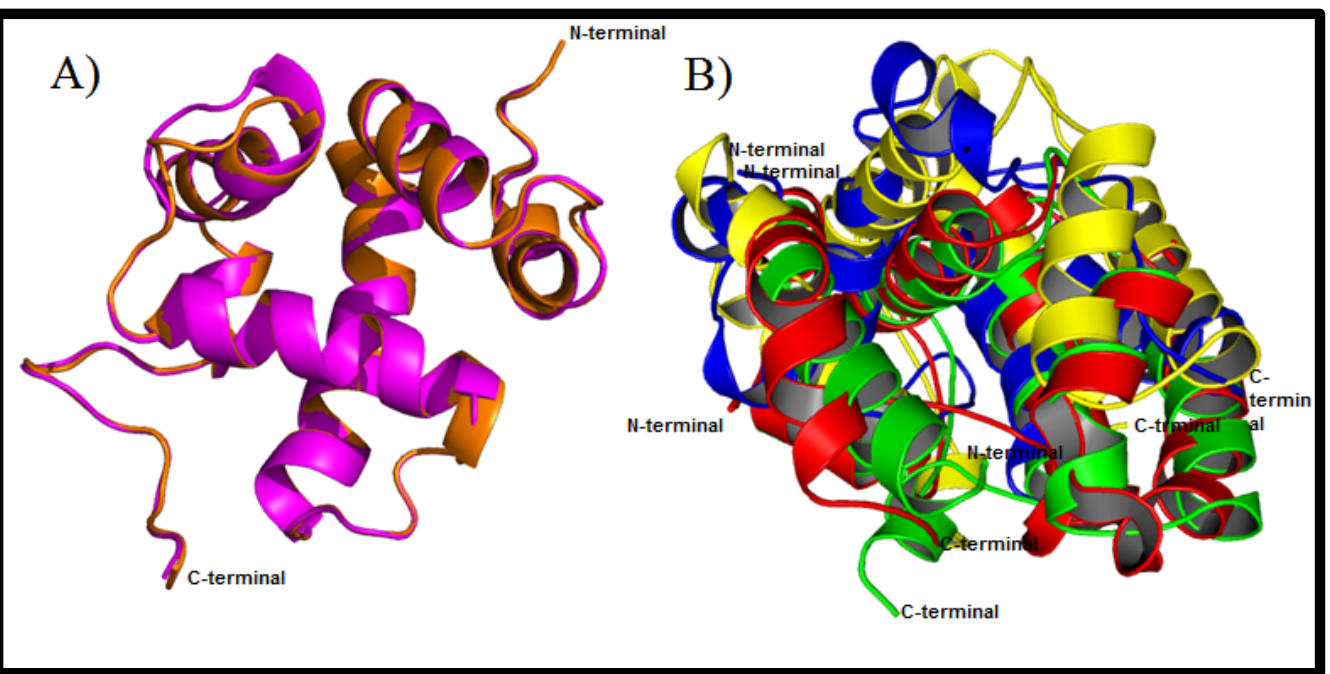

Figure 3: Superimposition of six OBPs taken from the phylogenetic tree. A) The two structures of OBPs from out group of phylogenetic tree (Pinkc color-ApisMillefera(model-Q8I6X7) and Orange color-Apis Cerana (Model-Q1W1D8). B) Superimposition of four OBPs from in-group of phylogenetic tree (Red-2H8V, Green-Model A0A0K0PXH2, Blue-Model A0A0K0PX79 and Yellow-Model Q1W1D7).

ISSN 0973-2063 (online) 0973-8894 (print)

Bioinformation 14(5): 219-231 (2018)
BIOMEDICAL INFORMATICS 


\section{BIOINFORMATION \\ Discovery at the interface of physical and biological sciences}

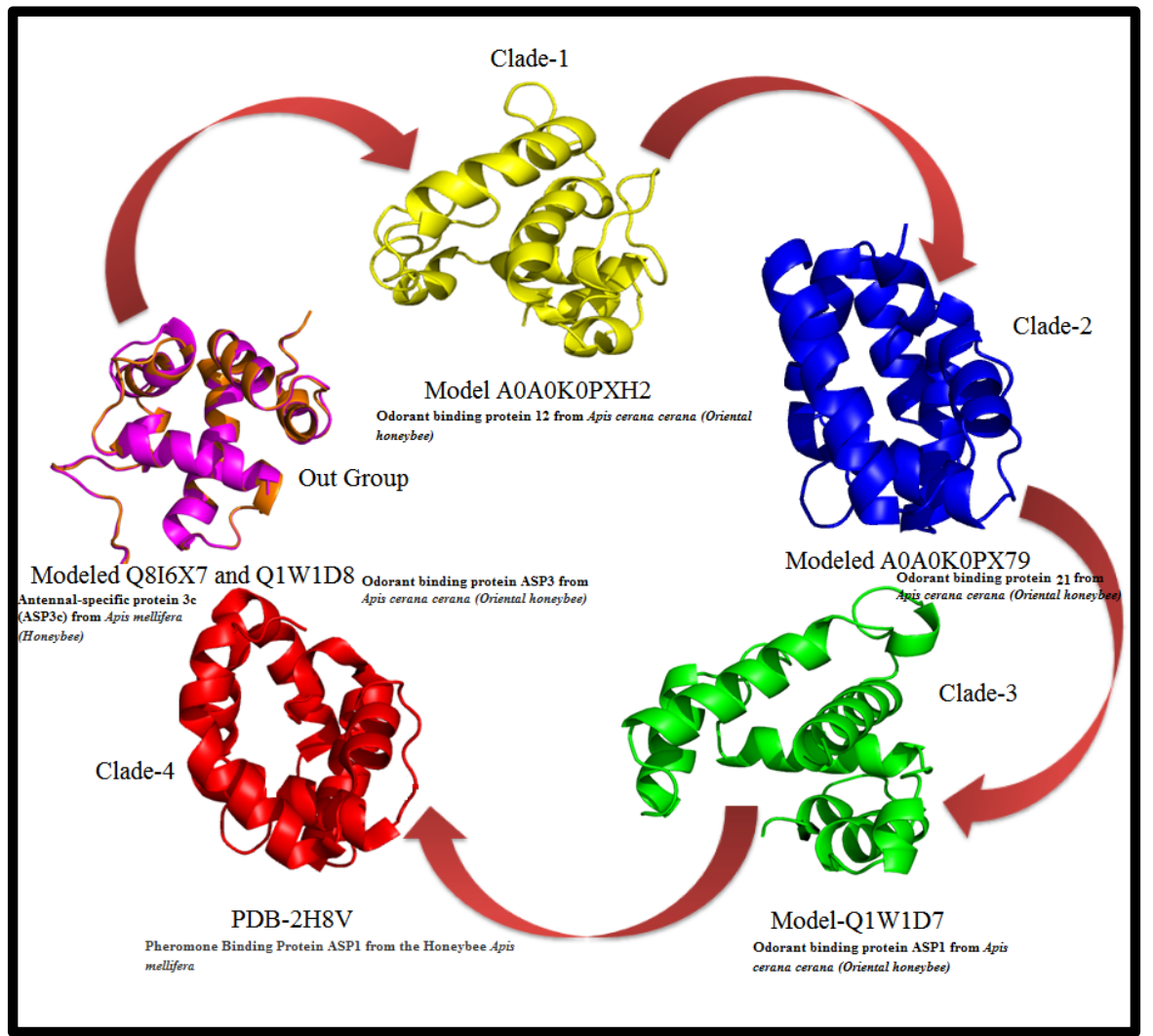

Figure 4: Structural evolutions of six OBPs taken from Phylogenetic tree.
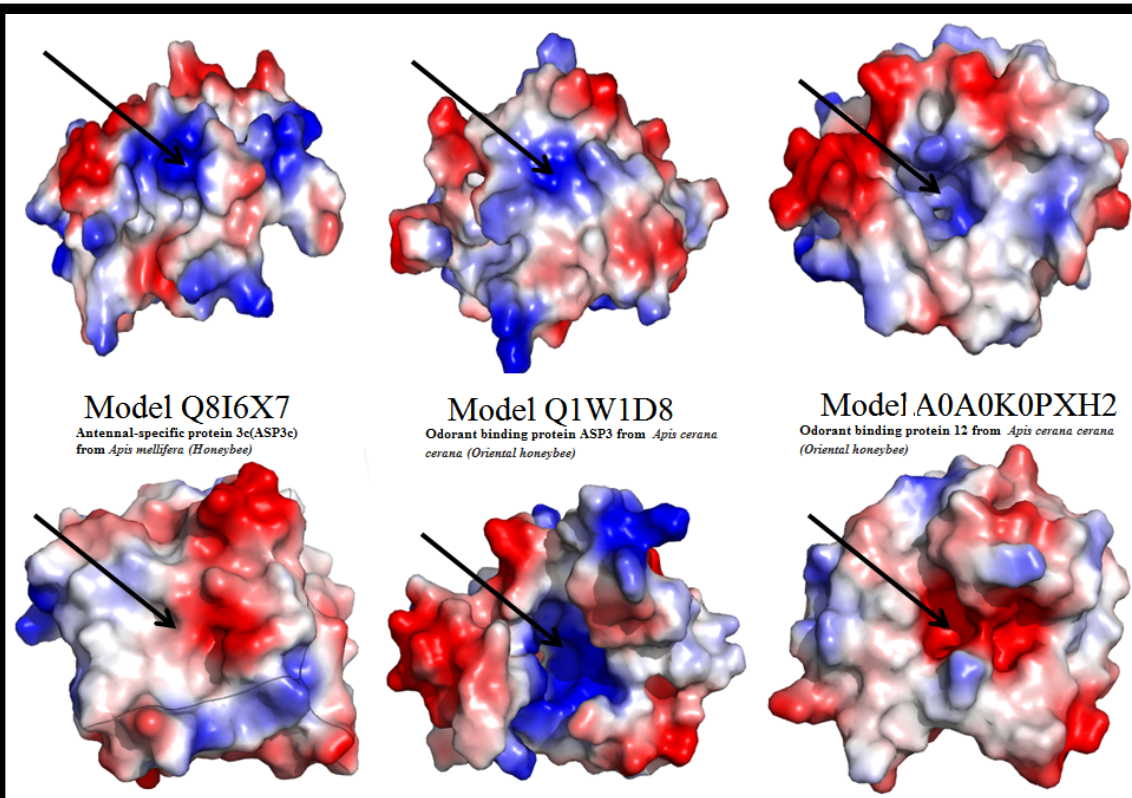

$\underset{\text { Odorant binding protein } 21 \text { from Apis cernena }}{\text { Model A0A } 0 \text { A }}$

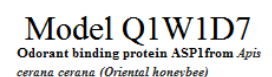

PDB-2H8V

Pheromone Binding Protein
ASPI from the Honeybee $A p i s$

Figure 5: Electrostatic surfaces of six structures from phylogenetic tree depicting the charge variation in the structures.

ISSN 0973-2063 (online) 0973-8894 (print)

Bioinformation 14(5): 219-231 (2018)
BIOMEDICAL

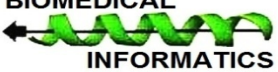




\section{BIOINFORMATION}

Discovery at the interface of physical and biological sciences

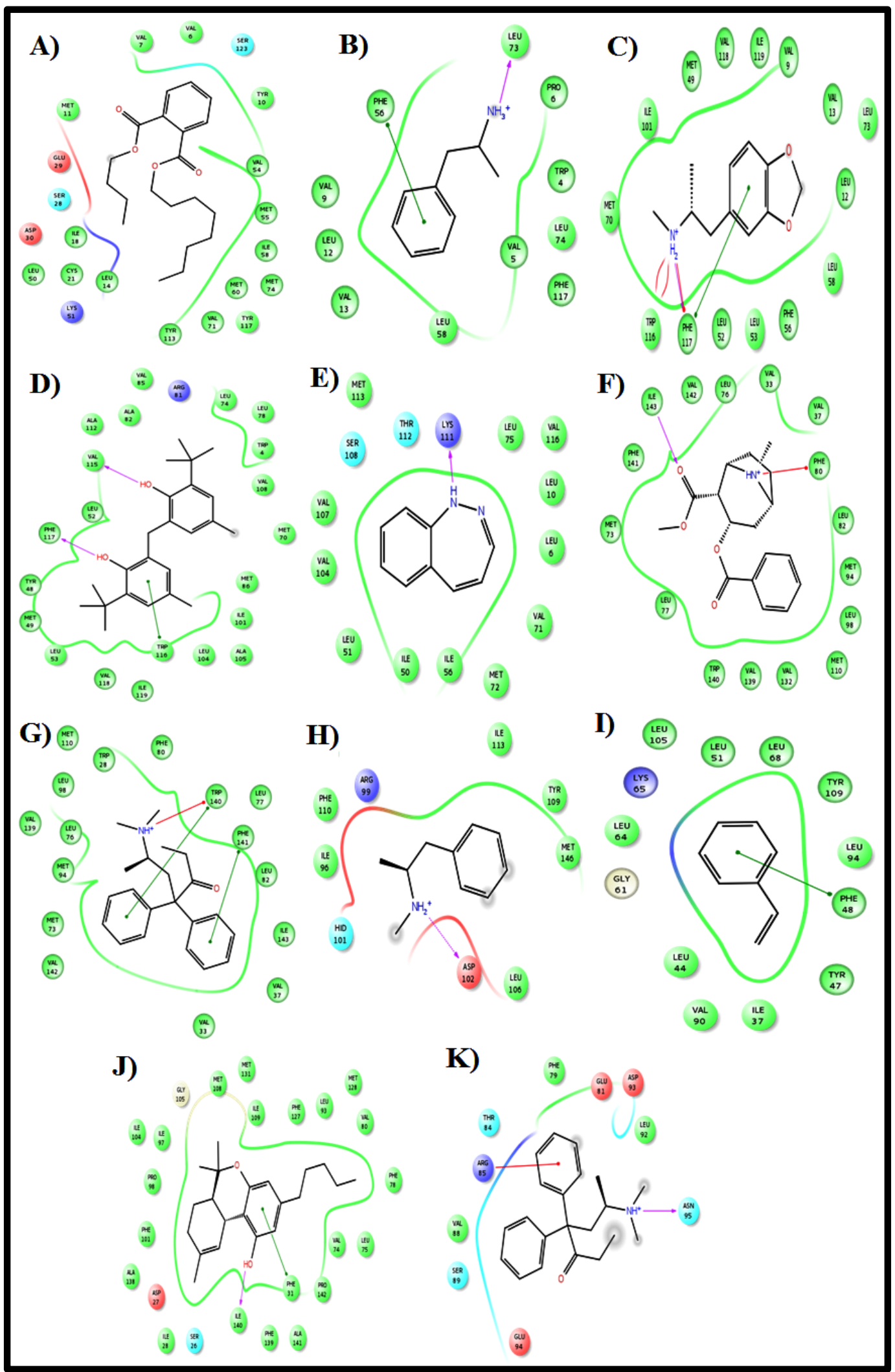

Figure 6: Interaction of Eleven Illicit drugs and bomb compounds with OBPs from honeybee

ISSN 0973-2063 (online) 0973-8894 (print)

Bioinformation 14(5): 219-231 (2018)

\section{Open access}




\section{BIOINFORMATION}

\section{Discovery at the interface of physical and biological sciences}
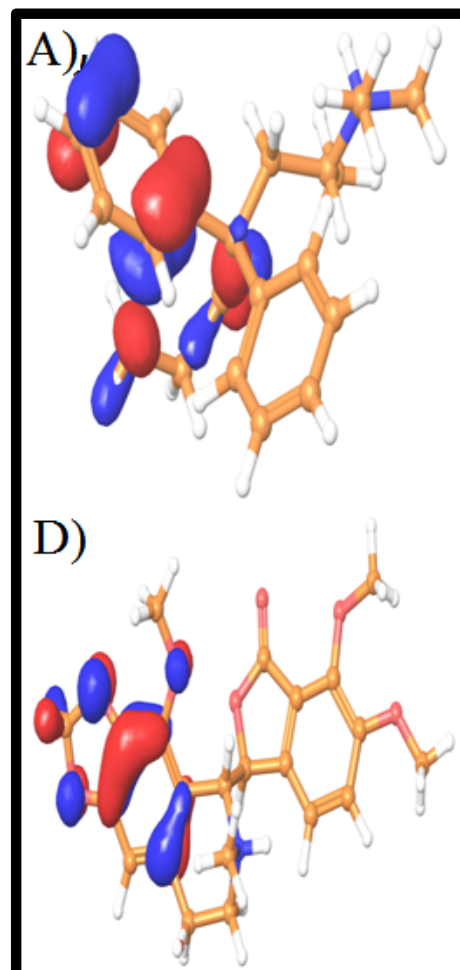

G)

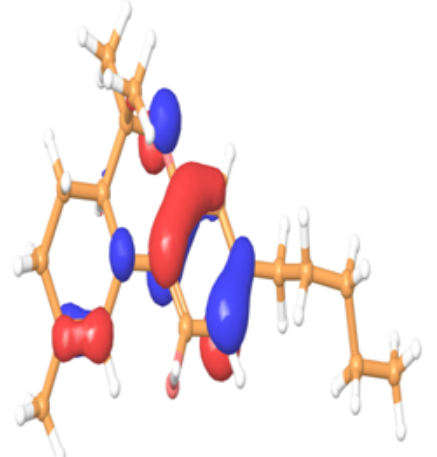

B)

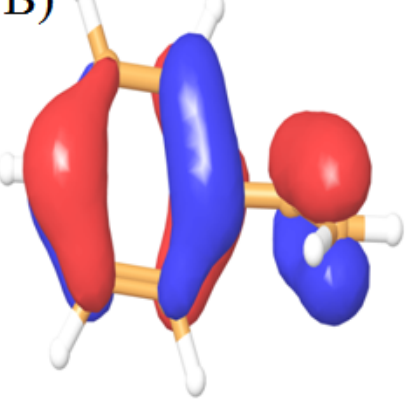

E)

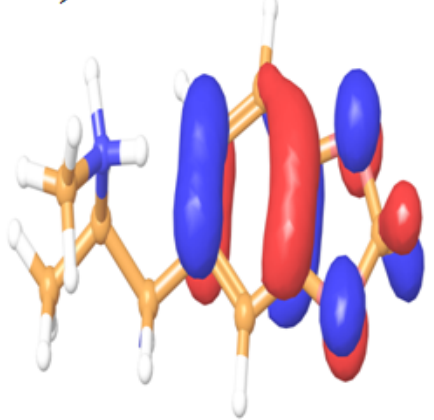

H)

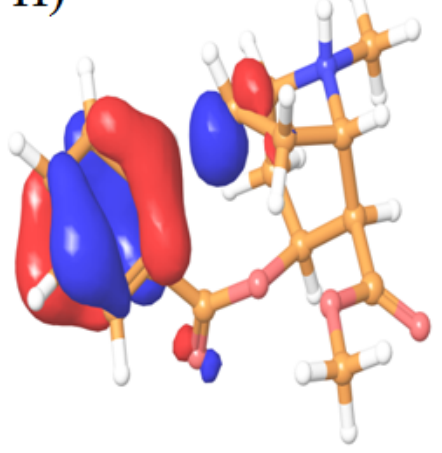

C)

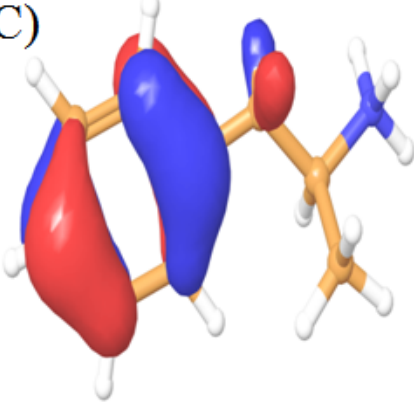

F)

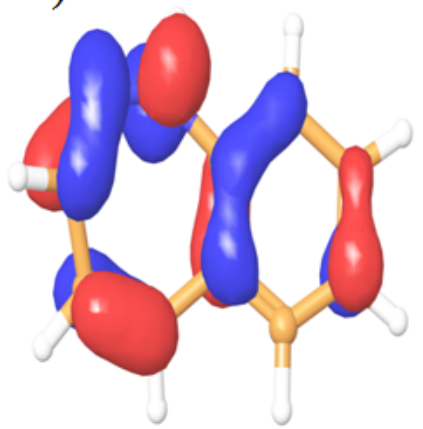

I)

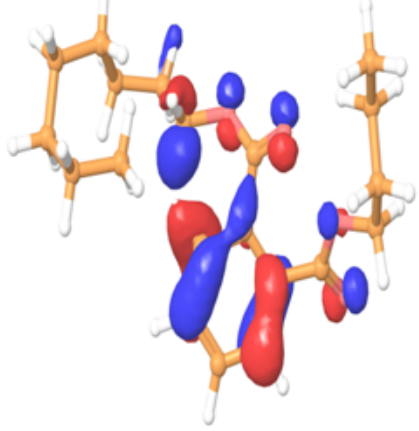

J)

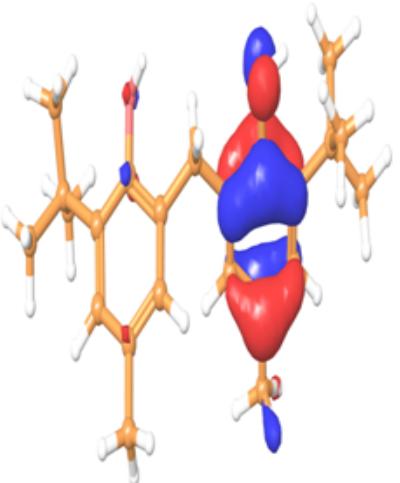

K)

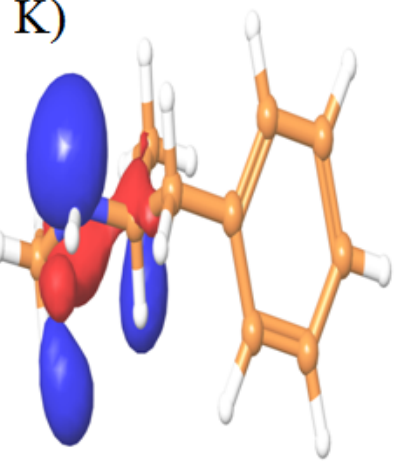

Figure 8: 3-D counter map analysis of Highest Occupied Molecular Orbital (HOMO) for eleven illicit drugs and bomb compounds. The eleven compounds are A) Methadone, B) Binder styrene Butadiene C) Amphetamine D) Narcotine E) Ectasy F) Benzodiazepine G) Dronobinal Cannabis H) Crack Cocaine I) Plasticizer J) N-Phenyl-2-Napthalamine and K) Methamphetamine.

ISSN 0973-2063 (online) 0973-8894 (print)

Bioinformation 14(5): 219-231 (2018)
BIOMEDICAL

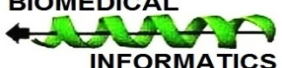




\section{BIOINFORMATION}

\section{Discovery at the interface of physical and biological sciences}

D)

G)
H)
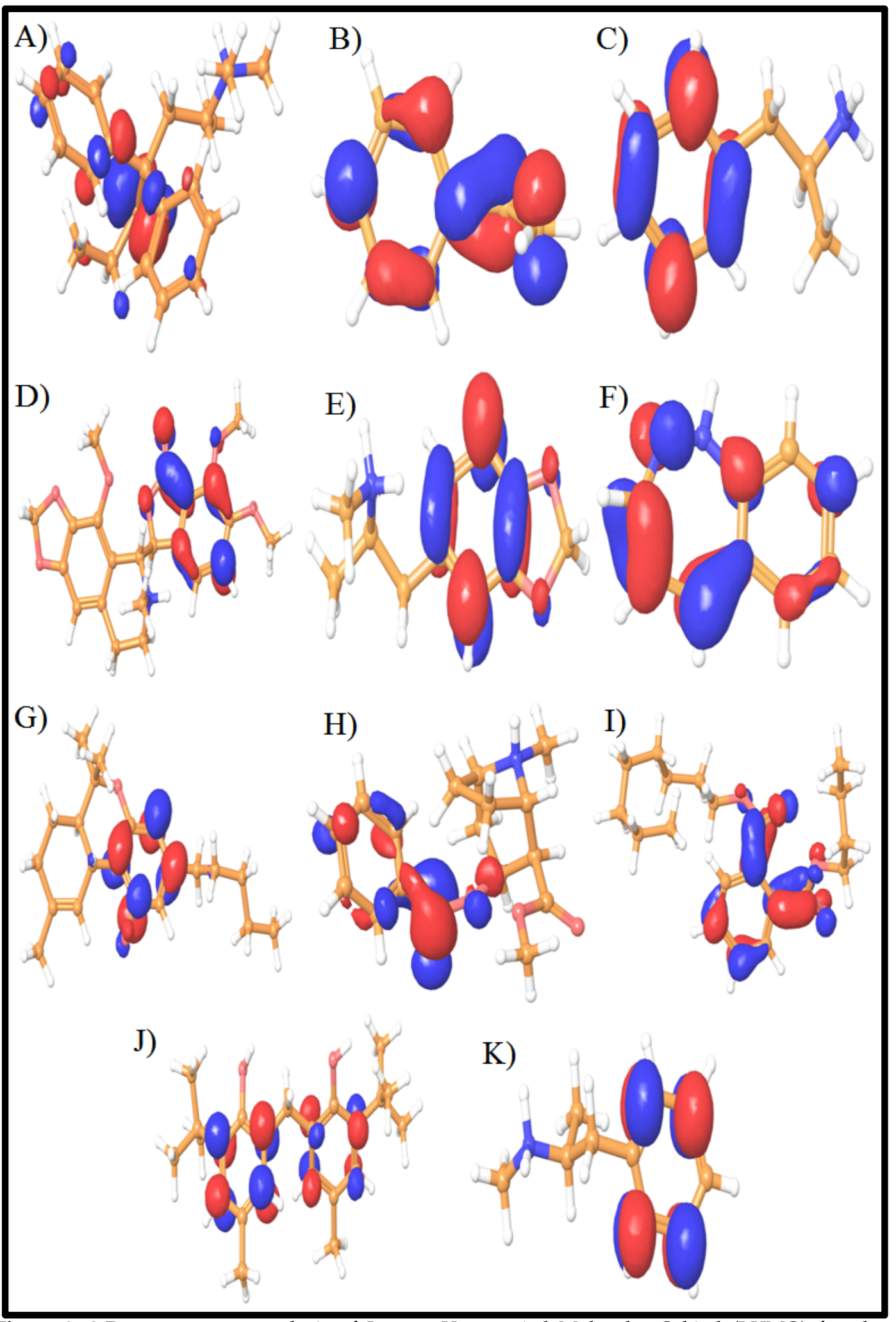

Open access

Figure 9: 3-D counter map analysis of Lowest Unoccupied Molecular Orbital (LUMO) for eleven illicit drugs drugs and bomb compounds. The eleven compounds are A) Methadone, B) Binder styrene Butadiene C) Amphetamine D) Narcotine E) Ectasy F) Benzodiazepine G) Dronobinal Cannabis H) Crack Cocaine I) Plasticizer J) N-Phenyl-2-Napthalamine and K) Methamphetamine.

ISSN 0973-2063 (online) 0973-8894 (print)

Bioinformation 14(5): 219-231 (2018)
BIOMEDICAL - 


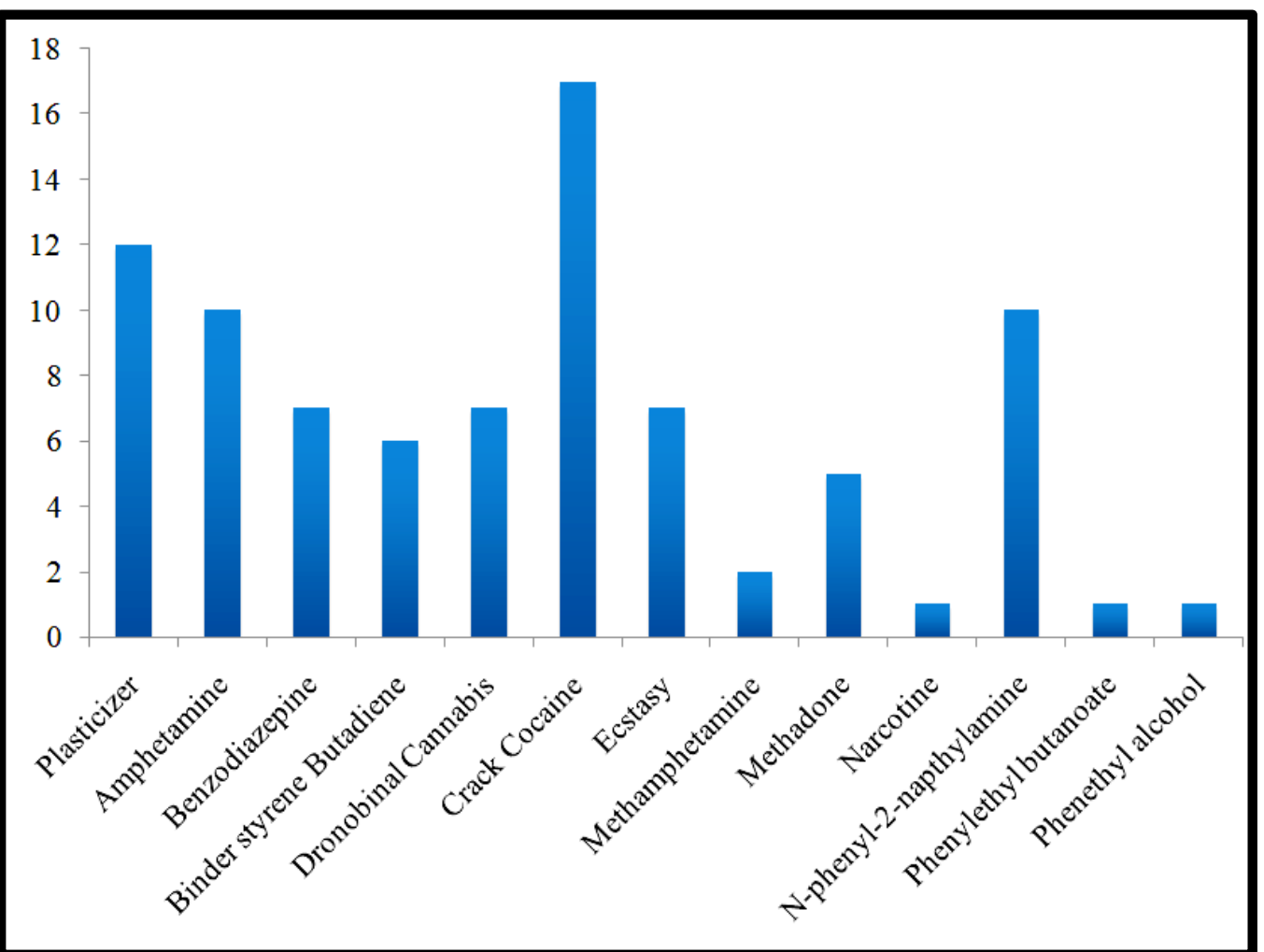

Figure 7: Binding selectivity of illicit drugs and bomb compounds with 43 OBPs. Top two docked compounds were accounted for the binding preference analysis.

\section{Conclusion:}

Analysis of OBP across distant phylogeny is of interest is the development of biosensor application. We report the binding of 19 compounds with 43 OBPs from distant phylogeny using modeling and docking analysis. Honeybees are important pollinator and it is used in the several ways, such as medical, agricultural, etc., and due to their learning power, it is used to detect bombs and some illicit drugs compounds. This extensive in silico approach is preliminary work to understand and explain the detecting mechanism of illicit drugs and bomb compounds, therefore we can overcome the solution by taking experimental evidence so far done. The phylogenetic tree analysis of OBPs from Apis Millefera and Apiscerana explains that proteins were highly similar in nature. Until now, Apis Millefera used for the detection and training illicit drugs, rather from this current study, Apis Cerana can be used to treat such training. The electrostatic interactions of OBPs are highly influenced the compound to bind and prefer the reaction to identify the location of sources. Consequently, the docking protocol had been helped to identify the binding preference and interaction of the compound to understand the biological function of proteins. Based on the docking, the binding preference and docking score of the complexes can be used to train or molecular level biosensor application to detect the illicit drugs and bomb compounds using honeybee. Also, the electronic feature of the compounds can be used to understand the chemical reactions to stimulate the memory power of OBPs. HOMO-LUMO regions and their energy gap define the chemical reaction of compounds with OBPs leads ISSN 0973-2063 (online) 0973-8894 (print) to understand the stimulating mechanism for finding the illicit drugs and bomb. Understanding the molecular interaction and chemical reaction of the compound may help to understand the fundamental of sensing reactions. Moreover, concentrating on these proteins at the molecular level will pave the potential role in the detection of illegal drugs and bomb compounds using honeybee.

\section{Acknowledgment:}

Dr. V.K. Langeswaran thanks Department of Bioinformatics, Alagappa University for computational facility. JJ thankfully acknowledges UGC, DBT and DST for the financial assistance. The authors thank UGC-Innovative program (F. NO. 14-13/2013 (Inno/ASIST) dated 30.03.2013) for providing the computational facilities.

\section{Conflict of interest:}

The authors declared that there are no conflicts of interest.

\section{References:}

[1] https://www.unodc.org/unodc/en/data-andanalysis/WDR-2012.html.

[2] Taylor MH \& Grossberg GT. The Primary Care Companion for CNS Disorders 2012. 14:PCC.11r01320. [PMID: 23251860]

[3] Schott $M$ et al. PLoS One. 2015, 10:e012852. [PMID: 26083377]

[4] Leitch $\mathrm{O}$ et al. Forensic Sci Int. 2013, 232:92. [PMID: 24053870] 
[5] Frederickx C et al. Biotechnol Agron Soc. 2011, 15:449.

[6] Amendt J et al. Naturwissenschaften. 2004, 91:51. [PMID: 14991142]

[7] Kirkerud NH et al. Front Behav Neurosci. 2013, 7:29 [PMID: 23616753]

[8] Room R. Addiction. 2014, 109:345. [PMID: 24180513]

[9] Park D et al. BMC Genomics. 2015, 16:1. [PMID: 25553907]

[10] Liang CH et al. Sci Rep. 2016, 6:23657. [PMID: 27005398]

[11] Karpe SD et al. Genome Biol Evol. 2016, 8:2879. [PMID: 27540087]

[12] Missbach C et al. Elife. 2014, 3:e02115. [PMID: 24670956]

[13] 12a https://www.technologyreview.com/s/406961/usingbees-to-detect-bombs/

[14] Li DZ et al. Int J Biol Sci. 2015, 11:1281. [PMID: 26435694]

[15] Venthur H et al. Physiological Entomology. 2014, 39:183.

[16] Kim S et al. Nucleic Acids Res. 2016, 44:D1202. [PMID: 26400175]

[17] The UniProt Consortium. Nucleic Acids Research. 2017, 45:D158. [PMID: 27899622]
[18] Arnold K et al. Bioinformatics. 2006, 22:95.

[19] Larkin MA et al. Bioinformatics. 2007, 23:2947.

[20] Marchler-Bauer A et al. Nucleic Acids Res. 2017, 45:D200. [PMID: 27899674]

[21] Kumar S et al. Mol Biol Evol. 2016, 33:1870. [PMID: 27004904]

[22] Surekha K et al. Gene. 2016, 583:102.

[23] Richard M et al. J Recept Signal Transduct Res. 2016, 36:233. [PMID: 26481897]

[24] Choubey SK et al. J Mol Graph Model. 2016, 70:54.

[25] Choubey SK et al. J Biomol Struct Dyn. 2016, $18: 1$.

[26] Halgren TAJ. Chem Inf Model. 2009, 49:377.

[27] https://www.schrodinger.com/Glide/

[28] https://www.schrodinger.com/pymol/

[29] https://www.schrodinger.com/Jaguar

[30] Choubey SK et al. J Mol Struct. 2016, 1125:391.

[31] Foret $S$ et al. Genome Research. 2006, 16:1404.

\section{Edited by P Kangueane}

Citation: Langeswaran et al. Bioinformation 14(5): 219-231 (2018) License statement: This is an Open Access article which permits unrestricted use, distribution, and reproduction in any medium, provided the original work is properly credited. This is distributed under the terms of the Creative Commons Attribution License 